\title{
THE STRUCTURE OF EMPLOYEES IN TOURISM INDUSTRY OF VOJVODINA (SERBIA) AS A GENDER INEQUALITY INDICATOR
}

DOI: http://dx.doi.org/10.18509/GBP.2019.60

UDC: 338.486.2:331.264.2]:305(497.113)

\author{
Vuk Garača \\ Svetlana Vukosav \\ Danka Curaković \\ Milan Bradić \\ Bojana Kalenjuk \\ Department of Geography, Tourism and Hotel Management, \\ Faculty of Natural Sciences, University of Novi Sad, Serbia.
}

\begin{abstract}
Gender inequality is a big problem of modern society, both in developed and undeveloped countries of Europe and the world. There are numerous and different ways of its manifestation in the economy in general, which also stands for tourism industry companies. The aim of this paper is to show gender inequality in the tourism industry of Vojvodina (Serbia) through the structure of employees. In this paper gender and educational structure of those employed in tourism and hospitality companies in Vojvodina (Serbia) was analysed. The author's research showed that men are dominant in positions of high management, while women with the same level of education are hard to come to those jobs and positions. In theory, this is known as a 'glass ceiling' barrier. Also, it was determined that women are more submissive to the crisis as it was during the global economic crisis, when they lost their jobs in the higher percentage than men. It is especially expressed with women with secondary and elementary education. The main methods used in the paper are: statistical, analytically synthetic and descriptive method. The correlation analysis was very important and it was used to draw a connection between ten-year statistical series in the period from 2008 to 2018.
\end{abstract}

Key words: gender inequality, the structure of employees, statistical analysis, tourism industry, Vojvodina (Serbia)

\section{INTRODUCTION}

Gender-sensitive statistics or gender statistics is a relatively new term which is connected with gathering of statistical data about men and women in one society, so that gender equality politics can be carried out [1]. Gender-sensitive statistics enables a rise of consciousness about problems, but is also a base for finding adequate solutions, or rational and beforehand creation of public politics and tracking their effects. It also, which is very important, influences on awakening women and their mobilization, because among other things shows their numerical strength [2]. It is quoted that gender-sensitive statistics was founded in Serbia by publication 'Women and men in Serbia' published by the Statistical office of the Republic of Serbia in 2005. Even though this thesis is widely spread in our country because it is related to term of 'gender sensitive statistics' which is new, the truth is that ex-SFRY had a gender-sensitive statistics during the 1970s. 
According to the new data [3] the rate of formal employment of women in Serbia is 31,6\% and men almost $15 \%$ more (45,7\%). According to [4] 25,5\% of women are self-employed, even though self-employed women that employ workers are $2,6 \%$ of employed women in general. The rate of inactive women is very high compared to the rate of inactive men. Out of working operational women from 15 to 65 years, most of them are inactive $(59,6 \%)$ and when it comes to men from the same age group that number is less than $50 \%(42,9 \%)$ [5]. The reasons for inactivity are different between men and women and they match traditional gender roles. From all persons, which in 2013 cited care of children or other persons, as reasons for their inactivity, 97\% are women and only 3\% are men. From all persons which were inactive during 2013, because of personal and family reasons, $84 \%$ are women and $16 \%$ are men [6]. Women are present in a higher percentage in the public sector, but they are less employed as managers. Gender differences in labour market are visible in sectors and jobs dominated both by men and women [7]. There is an equality in the area of education, with even slightly higher number of women, but a qualitative difference in segregation of educational profiles is kept. Data show that two-year schools and faculties are mostly enrolled and finished by women. Among enrolled students, women make 56\%, and 58\% among graduates [8]. Gender stereotypes in choosing jobs are weakening, but they are still strong. The citizens of Serbia think that painting apartment (80\%), fixing the computer (67\%), flying a plane $(64 \%)$ and driving a taxi $(52 \%)$ are men's jobs or most of citizen/ness of Serbia prefer these jobs are done by men. On the other hand, women are seen as more adequate for jobs like: taking care of a small child $(84 \%)$, cleaning an apartment $(80 \%)$ so as care of an older person $(77 \%)$ [9].

The position of men and women in the area of employment and work has a list of specificities, which differ from the type of job. However, what the most have in common are that there are still differences in the labour market. Gender inequality in labour market, as a structural characteristic, far away from disappearing is redefined [10]. In developed economies, the quality of job is different between gender, according to which there are more women than men employed in worse jobs and with worse working conditions [11], [12]. This inequality reflects in traditional elements such as unemployment, the height of salary, the type of labour contract and more temporary jobs. Adjusting between job and family continues to be a factor of conditioning where women differ from men in labour market [13].

Gender inequalities are present in the tourism industry. In spite of fast growth rates of employment in tourism and high work activity of the tourism industry in total market participation, tourism is characterised by big glint of employed people [14]. This is partially because in the tourism industry we have low paid jobs, with challenging work conditions and restrictive possibilities for growth, especially for women [15], [16], [17]. Even though the number of women involved in the tourism industry has increased, like for example through tourism development programs which encourage women to become entrepreneurs [18], women still face with great number of obstacles which manifest in vertical and horizontal segregation [19]. Beside season jobs, low salaries and decreased security of employment, one of the most important questions in tourism is related to working hours [20]. Long working hours, night shift, work during weekends and holidays determines achieving balance between work and life which makes thing harder for those employed in tourism. The tourism industry alludes long and inadequate working hours, which makes women to be in worse position than men because they are more engaged in households [21], [22]. 
Besides the fact that in tourism there are no specially developed quality indexes, the interest for marking the quality of work grows [23], [24] together with positioning women's positions on labour market in tourism in sense of discrimination with respect to salaries, but also vertical (a low number of highly positioned women) and horizontal segregation (feminised and masculinised activity). There are proofs which suggest that women are mostly placed on submissive workplaces and have lower salaries for a job done and that are more than men employed in temporary and occasional jobs and that only few of them get to high positions [25]. Without regard to country and variable, chosen and used during measurement, the results show that men are better paid than women in the same positions [26]. Several more studies show discrimination expressed through the salaries of men and women employed in tourism [26], [27], [28].

Further, the researches show a totally different division of salary between male and female employees in the hospitality sector, where women earn less than men [29], [30], [31], [32]. Gibelman [33] reveals significant differences in salaries according to gender in the service sector. It is quoted that during the 2000 s women earned $24 \%$ less than men, which is a decrease of gap when compared to 1979 when women earned $37 \%$ less than men.

The researches which deal with questioning gender differences in organisation and finding the data about 'glass ceiling' phenomenon which blocks women from getting higher paid jobs show that gender differences don't reflect only in unequal salaries [34], [35], [36]. Even though numerous researches show a greater presence of female managers, for example in the hotel industry more than in other industries, in reality there is a bigger possibility that female managers are mostly present in the first lines of management and in supervisory function (supervisors) [37]. However, in accordance with what has happened in other industries, due to the development of the tourism industry and women's qualifications, in the last two decades, we can see more women in positions of managers [38]. In spite of that and without regard to local and global politics which promote equality in all positions, the total increase in the number of women in managing positions is still low [39], [40], [41].

Based on previous experiences from viewed literature, and based on accessible data from the Statistical office of the Republic of Serbia, we came to the subject, aim and tasks of this paper. The subject of this paper is gender equality or inequality in tourism industry of the Autonomous Province of Vojvodina. The aim of this paper is to determine the existence and degree of quantitative signs of that inequality. The tasks of this paper are related to the research of individual indicators of gender inequality in the tourism industry which are statistically visible, such as: the number of employees according to gender, the percentage of employed men and women according to degree of professional qualification in total number of employees, the structure of employed according to degree of professional qualification within individual groups of employed women and men.

\section{METHODOLOGY}

Several methods were used during the research process 1) exploring the primary and secondary data; 2) statistical method and 3) synthetic, comparative, critical and descriptive method

Desk research involves studying primary and secondary data [42]. Through this method we got the statistical data about the number of employees according to gender, their structure according to their professional qualification, average earnings according to their 
gender, professional qualification and distribution of employees according to pay grade. The data delivered from official publications of the Statistical office of the Republic of Serbia, were used as the base on which series of data were formed for the period from 2008 to 2017. Domestic and foreign literature from the field of this work was also taken into account.

The statistical method consisted of a deep analysis of perennial statistical series of data about gender and educational structure of employees in the tourism industry of Vojvodina for the period from 2008 to 2017. Statistical data gathered during the first phase, so called desk research was treated by different statistical indicators such as average value, percentage and growth or decrease in the value of statistical data within the series [43]. Beside the listed ones, other methods were used in this paper: synthetical, where based on secondary and statistical data, through their systematical use some concrete conclusions were created; comparative, where statistical data were mutually compared; critical, when we took a critical attitude toward literature data and those data gathered by statistical analysis and descriptive with which certain result was explained.

\section{GENDER STRUCTURE}

Gender structure of employed people in tourism is one of the first indicators of gender equality, which clearly confirms those quotes from the introduction of this work connected to job division on men's and women's jobs. But, more than that deeper analysis of the percentual contribution of employed people according to gender, gives a real image about the position of one of the genders in one company, industry or total industrial system of a country.

It is not easy to statistically determine the number of employees in tourism, because tourism is an aggregation of economic and non-economic activities, which makes all of those who have a direct or indirect role in making touristic products and/or transfer of touristic service, statistically connected for totally different activities. Here should be noticed that this research includes employees in economic associations, companies, agencies, cooperatives and organisations in social, cooperative, mixed, state and private property. But, those employed in some small enterprises, with entrepreneurs, and in the Ministry of Defence and the Ministry of Internal Affairs are not included in this research; this means that number of employees and its structure shown in this work represents subaggregation of the total number of registered employment in the hospitality sector. That is why all the data shown in this paper, don't have a purpose of presenting the real number of employees in the tourism industry of Vojvodina, but just to check the structure of employed people according to gender, professional qualification and the height of salary.

Table 1. Number of employees in the accommodation and food and beverage sector according to gender

\begin{tabular}{lrrrrrrrrrr}
\hline Gender/Year & 2008 & 2009 & 2010 & 2011 & 2012 & 2013 & 2014 & 2015 & 2016 & 2017 \\
\hline Men & 849 & 645 & 632 & 603 & 578 & 533 & 517 & 914 & 956 & 1002 \\
Women & 1044 & 804 & 782 & 1414 & 665 & 651 & 611 & 1378 & 1409 & 1457 \\
\hline Total & 1893 & 1449 & 1414 & 1357 & 1243 & 1184 & 1128 & 2292 & 2365 & 2459 \\
\hline \multicolumn{8}{c}{ Source: Statistical office of the Republic of Serbia, } \\
Statement 3P12 - The employees with legal persons in Republic of Serbia, \\
according to to total amount of salary and professional qualification, during march (2008-2017)
\end{tabular}

But, here we can see a continuous decrease of $40,4 \%$ in the total number of employees in this sector from 2008 to 2014, where the number of employed women decreased in $41,5 \%$, men in $39,1 \%$, which is a $2,41 \%$ less decrease in the total number of employed 
men compared to women in the same period (Table 1). If we take into account the whole ten-year period, we can say that there is a recovery in the period from 2014 to 2017, where the total number of employed increased in $118 \%$, where the number of employed women increased in $138,5 \%$, while the number of men increased in $93,8 \%$. Compared to starting 2008., the total number of employed in 2017 is higher in $29,9 \%$. It is interesting here that crisis mostly affects women and in this case, we have confirmed drain of female labour force in 2,4\% higher than men in the conditions of global economic crisis.

Once the service sector, tourism especially was the basis for employing female labour force, mostly with elementary and secondary education on jobs related to kitchen, hotel household, restaurant and reception, so the percentage of employed women was significantly higher than the percentage of employed men. In modern times, that difference is significantly less $55,2 / 44,8 \%$ (2008), or 59,3/40,7\% (2017), which shows the growth in the percentage of women in labour force in the tourism industry of Vojvodina. But, during the economic crisis that trend is harmed with higher dismission of women 53,5/46,5\% (2012). During the observed ten-year period, the percentage of women employed in tourism is almost $4 \%$ higher, while the number of men decreased in the same percentage, which we can see in Table 2. It is important to emphasize that during the crisis, opposite processes happen like for example during the economic crisis, when in 2012 the total number of women decreased in 1,7\%, and the number of employed men increased in the same percentage. This clearly shows that women easily lose their jobs during the crisis, which can strike a company or society in global, which is a general indicator of gender inequality in Serbia.

Table 2. Number of employees in the accommodation and food and beverage sector according to gender structure (\%).

\begin{tabular}{lrrrrrrrrrr}
\multicolumn{10}{c}{ and beverage sector according to gender structure (\%). } \\
\hline Gender/Year & 2008 & 2009 & 2010 & 2011 & 2012 & 2013 & 2014 & 2015 & 2016 & 2017 \\
\hline Men & 44,8 & 44,5 & 44,7 & 44,4 & 46,5 & 45,0 & 45,8 & 39,9 & 40,4 & 40,7 \\
Women & 55,2 & 55,5 & 55,3 & 55,6 & 53,5 & 55,0 & 54,2 & 60,1 & 59,6 & 59,3 \\
\hline Total & 100 & 100 & 100 & 100 & 100 & 100 & 100 & 100 & 100 & 100 \\
\hline \multicolumn{8}{c}{ Source: Statistical office of the Republic of Serbia, }
\end{tabular}

Statement 3P12 - The employees with legal persons in Republic of Serbia, according to to total amount of salary and professional qualification, during march (2008-2017).

\section{EDUCATIONAL STRUCTURE}

Previously we have determined a higher percentage of women in the tourism sector for about 19 percent (2017), with an accent that this percentage is constantly growing in the period of economic stability, from 2012 to 2017. Tables 3 and 4 show the distribution of employed people according to gender and educational structure which will show, which jobs have more women employed considering a higher percentage of women in the total number of employees.

In decades before, the fact is that women in hospitality big systems had jobs with a necessary secondary and elementary professional qualification, so the structure of employees according to the degree of professional qualification reflected that condition. But, as time passes, so the percentage of women in this sector with a university and twoyear degree constantly increases, even during the economic crisis. So, the percentage of women with a university degree in the period from 2008 to 2017 increases by $11 \%$. What is interesting is that the percentage of women with a university degree increases during the economic crisis, so in 2010 this percentage was 66,3\%, and similar case is in two year degree, where in 2012 the percentage of women was $60 \%$ which 8,5\% more than in 2008 and $18,1 \%$ less than 2017. 
Table 3. Number of employees in the accommodation and food and beverage sector according to gender and educational structure (\%).

\begin{tabular}{lcccccccccc}
\hline Year/Qualification & 2008 & 2009 & 2010 & 2011 & 2012 & 2013 & 2014 & 2015 & 2016 & 2017 \\
\hline \multicolumn{1}{c}{ Gender } & $\mathrm{M}$ & $\mathrm{M}$ & $\mathrm{M}$ & $\mathrm{M}$ & $\mathrm{M}$ & $\mathrm{M}$ & $\mathrm{M}$ & $\mathrm{M}$ & $\mathrm{M}$ & $\mathrm{M}$ \\
University degree & 56,4 & 42,5 & 33,8 & 40,0 & 48,0 & 35,2 & 45,7 & 44,0 & 45,0 & 45,4 \\
Two-year degree & 48,5 & 45,9 & 43,5 & 40,7 & 40,0 & 41,2 & 47,5 & 46,6 & 47,2 & 58,1 \\
Secondary edu. & 49,6 & 50,5 & 47,2 & 49,0 & 50,1 & 51,1 & 49,2 & 42,6 & 42,3 & 41,5 \\
Elementary edu. & 30,4 & 17,4 & 38,0 & 37,5 & 48,3 & 48,6 & 32,1 & 33,3 & 43,5 & 27,3 \\
$H S$ & 44,1 & 51,9 & 60,6 & 55,6 & 72,7 & 79,2 & 55,8 & 58,3 & 50,0 & 58,6 \\
$S$ & 48,3 & 47,1 & 51,9 & 50,0 & 49,1 & 49,2 & 50,9 & 44,2 & 45,9 & 44,0 \\
LS & 31,0 & 40,9 & 41,2 & 29,0 & 37,9 & 33,3 & 37,9 & 7,7 & 7,0 & 7,7 \\
US & 25,1 & 22,1 & 27,4 & 19,7 & 25,5 & 16,2 & 29,3 & 28,2 & 23,4 & 31,9 \\
\hline
\end{tabular}

Source: Statistical office of the Republic of Serbia,

Statement 3P12 - The employees with legal persons in Republic of Serbia,

according to to total amount of salary and professional qualification, during march (2008-2017).

This could mean that the owners of the capital during critical situations have more trust in highly educated women than men. Besides that, men in higher management have more courage to leave a less paid job and search for a better one, while women don't take that steps very often. When it comes to employees with secondary education, there are no significant changes during the crisis, while their involvement at the end of the observed period 2017. increase by $8 \%$. At the employees with other degrees of professional education, there is a decrease in the percentage of female labour force: elementary 7,9\%, HS $28,6 \%, \mathrm{~S} 0,8 \%$, LS $6,79 \%$ and US $0,4 \%$. That is typical in crisis situations, when women with lower degrees of professional qualification lose their jobs, as the most vulnerable category of employed people of those easily replaceable. After the economic crisis until 2017, the percentage of women in mentioned categories grows: elementary $21 \%$, HS $14,1 \%, \mathrm{~S} 5,1 \%$, LS $30,1 \%$, except in US where there is a decrease in $6,4 \%$.

Table 4. Number of empoyees in the accommodation and food and beverage sector according to gender and educational structure $(\%)$.

\begin{tabular}{lcccccccccc}
\hline Year/Qualification & 2008 & 2009 & 2010 & 2011 & 2012 & 2013 & 2014 & 2015 & 2016 & 2017 \\
\hline \multicolumn{1}{c}{ Gender } & $\mathrm{W}$ & $\mathrm{W}$ & $\mathrm{W}$ & $\mathrm{W}$ & $\mathrm{W}$ & $\mathrm{W}$ & $\mathrm{W}$ & $\mathrm{W}$ & $\mathrm{W}$ & $\mathrm{W}$ \\
University degree & 43,6 & 57,5 & 66,3 & 60,0 & 52,0 & 64,8 & 54,3 & 56,0 & 55,0 & 54,6 \\
Two-year degree & 51,5 & 54,1 & 56,5 & 59,3 & 60,0 & 58,8 & 52,5 & 53,4 & 52,8 & 41,9 \\
Secondary edu. & 50,4 & 49,5 & 52,8 & 51,0 & 49,9 & 48,9 & 50,8 & 57,4 & 57,7 & 58,5 \\
Elementary edu. & 69,6 & 82,6 & 62,0 & 62,5 & 51,7 & 51,4 & 67,9 & 66,7 & 56,5 & 72,7 \\
$H S$ & 55,9 & 48,1 & 39,4 & 44,4 & 27,3 & 20,8 & 44,2 & 41,7 & 50,0 & 41,4 \\
$S$ & 51,7 & 52,9 & 48,1 & 50,0 & 50,9 & 50,8 & 49,1 & 55,8 & 54,1 & 56,0 \\
LS & 69,0 & 59,1 & 58,8 & 71,0 & 62,1 & 66,7 & 62,1 & 92,3 & 93,0 & 92,3 \\
US & 74,9 & 77,9 & 72,6 & 80,3 & 74,5 & 83,8 & 70,7 & 71,8 & 76,6 & 68,1 \\
\hline
\end{tabular}

Source: Statistical office of the Republic of Serbia,

Statement 3P12 - The employees with legal persons in Republic of Serbia, according to to total amount of salary and professional qualification, during march (2008-2017).

Beside the structure of employees according to gender and educational structure which is shown in tables 3 and 4, where the relation in every mentioned degree was observed, it is very interesting to look at the structure of employees according to professional qualification within gender structures, which means the percentage of certain degrees of professional qualifications in the corpus of the total number of employed men and the corpus of all employed women in the observed sector, which belongs to activities considered as a part of tourism (Table 5 and 6). Particularly, even though everything looks normal, some inequalities can be noticed within the male and female corpus. Firstly we should emphasize clearly exposed trend in the increase of percentage of a university 
degree and secondary education of professional qualification and HS, S, LS, US professional qualification. But, this is a totally natural process which is a consequence of global social prosperity in the sphere of education and contemporary demands of the profession, in this case, tourism or the accommodation and food and beverage sector.

Table 5. Structure of employed men the accommodation and food and beverage sector, according to the degree of professional qualification (\%).

\begin{tabular}{lrrrrrrrrrr}
\hline Year/Qualification & 2008 & 2009 & 2010 & 2011 & 2012 & 2013 & 2014 & 2015 & 2016 & 2017 \\
\hline Gender & $\mathrm{M}$ & $\mathrm{M}$ & $\mathrm{M}$ & $\mathrm{M}$ & $\mathrm{M}$ & $\mathrm{M}$ & $\mathrm{M}$ & $\mathrm{M}$ & $\mathrm{M}$ & $\mathrm{M}$ \\
University degree & 5,2 & 5,3 & 4,3 & 6,6 & 8,3 & 8,1 & 9,3 & 15,2 & 16,4 & 15,2 \\
Two-year degree & 5,8 & 14,7 & 5,9 & 5,5 & 4,5 & 5,3 & 5,4 & 5,3 & 5,3 & 5,4 \\
Secondary edu. & 44,5 & 46,2 & 47,5 & 54,4 & 55,0 & 54,0 & 49,3 & 51,0 & 44,9 & 49,7 \\
Elementary edu. & 0,8 & 1,9 & 6,5 & 1,5 & 2,4 & 6,4 & 3,5 & 2,5 & 3,9 & 2,4 \\
$H S$ & 8,8 & 2,2 & 3,2 & 2,5 & 2,8 & 3,6 & 4,6 & 2,3 & 1,9 & 3,4 \\
$S$ & 24,6 & 21,7 & 23,6 & 23,4 & 18,9 & 16,9 & 17,0 & 17,0 & 22,7 & 19,4 \\
$L S$ & 3,2 & 4,2 & 3,3 & 1,5 & 1,9 & 2,3 & 4,3 & 1,2 & 1,0 & 1,0 \\
US & 7,1 & 3,9 & 5,9 & 4,6 & 6,2 & 3,6 & 6,6 & 5,6 & 3,9 & 3,6 \\
\hline Total & 100 & 100 & 100 & 100 & 100 & 100 & 100 & 100 & 100 & 100 \\
\hline \multicolumn{8}{c}{ Source: Statistical office of the Republic of Serbia, } & &
\end{tabular}

What is symptomatic, and it has to do with the gender inequality is the fact that in the total number of employed men, the percentage of those with high professional qualification is bigger than the percentage of women with a same professional qualification. That difference in 2008 was $1,9 \%(\mathrm{M} / \mathrm{W})$ and somewhat smaller when compared in 2017 when it was $2,6 \%$ in favour of men, which means that the gap is increasing instead of decreasing. A two-year degree is slowly but steadily vanishing as a level of education, but here we can also see the situation that in the total number of employed men/women in 2017 stronger gender is more present. $(5,4 \% / 2,7 \%)$ Beside that, in comparison with 2008, this percentage of female in tourism industry cut in half $(5,0 / 2,7 \%)$, while in the structure of men this degree of professional qualification is almost unchanged. It is similar with secondary education, with the difference that this gap is decreasing in favour of women. But, even though they are less present in the total number of employees, their percentage in secondary education is still higher compared to the percentage of women. This difference in 2008 was $7,7 \%(\mathrm{M} / \mathrm{W})$, while 10 years later in 2017 it was $1,5 \%(\mathrm{M} / \mathrm{W})$.

Table 6. Structure of employed women in the accommodation and food and beverage sector, according to degree of professional qualification (\%).

\begin{tabular}{|c|c|c|c|c|c|c|c|c|c|c|}
\hline Year/Qualification & 2008 & 2009 & 2010 & 2011 & 2012 & 2013 & 2014 & 2015 & 2016 & 2017 \\
\hline Gender & $\mathrm{W}$ & $\mathrm{W}$ & $\mathrm{W}$ & $\mathrm{W}$ & $\mathrm{W}$ & $\mathrm{W}$ & $\mathrm{W}$ & $\mathrm{W}$ & $\mathrm{W}$ & $\mathrm{W}$ \\
\hline University degree & 3,3 & 5,7 & 6,8 & 5,7 & 7,8 & 12,1 & 9,3 & 12,8 & 13,6 & 12,6 \\
\hline Two-year degree & 5,0 & 13,9 & 6,1 & 6,0 & 5,9 & 6,1 & 5,1 & 4,0 & 4,0 & 2,7 \\
\hline Secondary edu. & 36,8 & 36,3 & 42,8 & 44,9 & 47,7 & 42,4 & 43,0 & 45,6 & 41,5 & 48,2 \\
\hline Elementary edu. & 1,5 & 7,1 & 8,6 & 7,6 & 2,3 & 5,5 & 6,2 & 3,3 & 3,4 & 4,4 \\
\hline$H S$ & 9,1 & 1,6 & 1,7 & 2,3 & 0,9 & 0,8 & 3,1 & 1,1 & 1,3 & 1,6 \\
\hline$S$ & 21,5 & 19,5 & 17,6 & 20,3 & 17,0 & 14,3 & 13,9 & 14,2 & 18,2 & 17,0 \\
\hline$L S$ & 5,7 & 4,9 & 3,8 & 3,6 & 2,7 & 3,7 & 5,9 & 9,5 & 9,4 & 8,2 \\
\hline$U S$ & 17,1 & 10,9 & 12,5 & 9,5 & 15,8 & 15,1 & 13,4 & 9,4 & 8,6 & 5,3 \\
\hline Total & 100 & 100 & 100 & 100 & 100 & 100 & 100 & 100 & 100 & 100 \\
\hline
\end{tabular}

Source: Statistical office of the Republic of Serbia,

Statement 3P12 - The employees with legal persons in Republic of Serbia, according to to total amount of salary and professional qualification, during march (2008-2017). 
It has been told that the percentage of HS, S, LS and US is generally decreasing and that is a general trend. However, the percentage of LS workers in the female corpus of employed people is growing swiftly starting from 2012 till 2017 when this percentage has more than doubled $(2,7 / 8,2 \%)$, herewith that in the period from 2008 till 2014 there is a constant decrease in the percentage of this degree of professional qualification in total number of employed women. In accordance with that, not just the percentage of LS workers in the total number of employed women has increased, but also the difference in the percentage of LS workers in men's and women's corpus in favour of women. In 2018 this difference was $2,5 \%$, while in 2017 it is 7,2, which means that difference has doubled in favour of women, which additionally shows the different (worse) educational structure in the women's corpus of employed people, compared to the structure of men's corpus.

\section{CONCLUSION}

Literature quotes showed that there are numerous forms of gender inequality in almost all segments of society, which are manifested in different ways. Some of them are qualitative and in that sense hidden from the public, but some of them are quantitative and easier to discern, for somebody who observes a certain phenomenon from the side. In case of this paper, the theme of analysis was statistical, or quantitative data gathered and published by Statistical office of the Republic of Serbia, which on first sight showed that there are certain harms in gender equality in the tourism industry of Vojvodina or in the accommodation and food and beverage sector as its biggest part. Thanks to the fact that the data gathered and published RSO, are in some way gender sensitive, it was possible to inquire this social phenomenon in one part of the industrial system of the Autonomous Province of Vojvodina. If this 'gender sensitivity' included higher spectre of statistical parameters, the results of this research would have been more specific in showing the type and level of gender inequality.

Particularly, it has been clearly determined, that women are more submissive to the crisis situations, as in global plan, but also in the inner plan of a company. During the global economic crisis, which consequences also felt in AP of Vojvodina, the percentage of employed women in the tourism industry has decreased in $2,4 \%$, while the number of employed men has increased in the same percentage. Actually, in given circumstances 2012 happened the decrease in the total number of employed people in $34,9 \%$, but women participated with $36,3 \%$ and men in $31,9 \%$. To that, it should be emphasized that women with the highest degrees of professional qualification were not exposed to this negative influence, just those with secondary and elementary education. So there is a logical question: Why both genders don't share an equal burden of crisis situations, but women suffer more?

Statistical data clearly show that women prevail in the total number of employed people, which is logical considering type of work. But, if we compare the percentage of employees according to gender with the share of every degree of professional qualification with regard to gender, it can be noticed that the percentage of men's labour force is always higher than the average, when it comes to higher degrees (university degree, two-year degree, secondary education, HS and S), while women's labour force is more present in lower degrees (elementary education, LS and US). Truly, this difference decreases during the years, but is still less visible in all above mentioned levels of professional qualification, so in 2017, in the accommodation and food and beverage sector with regard to gender there are less women in : 4,7 \% with university degree, 17,9 
with two-year degree, 0,8 with secondary education, $17,9 \mathrm{HS}$ and $3,3 \% \mathrm{~S}$, but more in: $13,4 \%$ with elementary, $33 \%$ HS and $8,8 \%$ US professional qualification. Here we have very clear, but not so obvious form of gender inequality.

Furthermore, it is very symptomatic, that in the total number of employed men, the percentage of those with higher professional qualification is always higher compared to the percentage of women with the same professional qualification. This difference is in the range from 2,2 to $2,6 \%$ in favour of men, in the period from 2008 to 2017, which means that the gap is not decreasing and that women still can't take over their working and social role in an industrial system of AP of Vojvodina.

Statistical data are stern and witness very accurately about quantitative differences which exist in the treatment of women and relation between women and women, or better say about the valuation of their work, abilities, intellect and wishes just because they are 'weaker' gender. In some future researches, more attention will be paid to qualitative indicators which represent real reasons and source of this condition of gender equality in the tourism industry of AP of Vojvodina. This is challenging because it will discover how glass floors and glass ceilings are created and what obstacles are in front of women and their career advancement. Also, it will be discovered what is objective and what less objective reason why an employed woman makes a decision not to advance or the system disables her in that intention.

\section{REFERENCES}

[1] Blagojevic Hjuson, M. Gender barometer in Serbia: development and everyday life. Belgrade: UN Women Srbiji, 2012.

[2] Balon, B. Gender sensitive statistics as a necessary element of society democratization. Sitizens vol. 1/2007, 2007.

[3] Canvass about labour force in Republic of Serbia 2014, Statistical office of the Republic of Serbia, Belgrade, 2018.

[4] Babović, M. The starting study about women's entrepreneurship UN women, 2012.

[5] Statistical yearbook of the Republic of Serbia, Republic Institute for Statistics, Belgrade, 2014.

[6] Canvass about labour force in the Republic of Serbia 2015, Statistical office of the Republic of Serbia, Belgrade, 2018.

[7] Canvass about labour force in the Republic of Serbia 2013, Statistical office of the Republic of Serbia, Belgrade, 2018.

[8] Statistical yearbook of the Republic of Serbia, Republic Institute for Statistics, Belgrade, 2015.

[9] Hughson, M., Bacanović, V. Gender equality in Serbia 2014: The analysis of state in economy, Institute of criminological and sociological research, 2014

[10] Torns, T., Recio, C. Las desigualdades de genero en el mercado de trabajo: entre la continuidad y la transformacion. Revista de Economia Critica, vol. 14, pp. 178-202, 2012.

[11] Duenas, D., Iglesias, C., Llorente, R. Job quality, job satisfaction and services in Spain, Journal of Innovation Economics: Innovations and Performances in Services, vol. 5, pp. 145-166, 2010.

[12] Mahadea, D. On the economics of happiness: the influence of income and non-income factors on happiness, South African Journal of Economic and Management Sciences, vol. 16(1), pp. 39$51,2013$. 
[13] Santero-Sanchez, R., Segovia-Pérez, M., Castro-Nuñez, B., Figueroa-Domecq, C., TalónBallestero, P. Gender differences in the hospitality industry: A job quality index. Tourism Management, vol. 51, pp. 234-246, 2015

[14] Kim, N. Employee turnover intention among newcomers in travel industry, International Journal of Tourism Research, vol. 16 (1), pp. 56-64, 2014.

[15] Baum, T. Human resources in tourism: Still waiting for change, Tourism Management, vol. 28, pp.1383-1399, 2007.

[16] Carvalho, I., Costa, C., Lykke, N., Torres, A. An analysis of gender employment in the Portuguese tourism sector, Journal of Human Resources in Hospitality \& Tourism, vol. 13 (4), pp. 405-429, 2014.

[17] Costa, C., Carvalho, I., Caçador, S., Breda, Z. Future higher education in tourism studies and the labor market: Gender perspectives on expectations and experiences, Journal of Teaching in Travel \& Tourism, vol. 12, pp. 70-90, 2012.

[18] Singh, S. Deconstructing "gender and developmen" for "identities of wome", International Journal of Social Welfare, vol. 16, pp. 100-109, 2007.

[19] Ramos, V., Rey-Maqueira, J., Tugores, M. Análisis empírico de discriminación por razón de género en una economía especializada en turismo, Annals of Tourism Research En Español, vol. 4 (1), pp. 239-258, 2002.

[20] Stacey, J. Supporting Quality Jobs in Tourism, OECD Tourism Papers, 2015/02, Paris Technology, National Council for Research of Women, World Trade Bank, New York, 2015.

[21] Doherty, L. The future is female, Hospitality, June, pp. 20-21, 1999.

[22] Guerrier, Y. Hotel manager-An unsuitable job for a woman? Service Industries Journal, vol. 6 (2), pp. 227-240, 1986.

[23] Blake, A., Arbache, J. S., Sinclair, M. T., Teles, V. Tourism and poverty relief, Annals of Tourism Research, vol. 35(1), pp. 107-126, 2008.

[24] Lacher, R. G., Oh, C.-O. Is tourism a low-income industry? Evidence from three coastal regions, Journal of Travel Research, vol. 51 (4), pp. 464-472, 2012.

[25] Richter, L. K. Gender and race: Neglected variables in tourism research, In R. Buffer, \& D. Pearce (Eds.), Change in tourism: People, places, Processes, Routledge, LondoH, 1995.

[26] García-Pozo, A., Campos-Soria, J. A., Sanchez-Ollero, J. L., Marchante-Lara, M. The regional wage gap in the Spanish hospitality sector based on a gender perspective, International Journal of Hospitality Management, vol. 31, pp. 266-275, 2012.

[27] Munoz-Bullon, F. The gap between male and female pay in the Spanish tourism industry, Tourism Management, vol. 30 (5), pp. 638-649, 2009.

[28] Baum, T. International perspectives on women and work in hotels, catering and tourism, International Labour Office, Geneva, Switzerland, 2013.

[29] Biswas, R. and Cassell, C. Strategic HRM and the Gendered Division of Labour in the Hotel Industry: A Case Study, Personnel Review, vol. 25/2, pp. 19-34, 1996.

[30] Purcell, K. The relationship between career and job opportunities: women's employment in the hospitality industry as a microcosm of women's employment, Women In Management Review, 11/5, pp. 17-24, 1996.

[31] Sparrowe, R.T., Iverson, K.M., Cracks in the glass ceiling? An empirical study of gender differences in income in the hospitality industry, Journal of Hospitality and Tourism Research, vol. 23/1, pp. 4-20, 1999.

[32] Evers, A. and Sieverding, M. Why do Highly Qualified Women (Still) Earn Less? Gender Differences in Long-Term Predictors of Career Success, Psychology of Women Quarterly, vol. 38, pp. 93-106, 2014. 
[33] Gibelman, M. Progress or complacency? Pay equity for Women Circa 2001 Affilia vol. 17 (3), pp. 279-298, 2002.

[34] Silberman, R.G., Executive intelligence: a glass ceiling. Restaurant Hospitality 75, pp. 65, 1991.

[35] Umbreit, W.T., Diaz, P.E. Women in hospitality management: an exploratory study of occupation choice variables, Hospitality and Tourism Educator vol. 6 (4), pp. 7-9, 1994.

[36] Morrison, A.M., Von Glinow, M.A., Women and minorities in management. American Psychologist vol. 45, pp. 20-208, 1990.

[37] Maxwell, A.G. Hotel general management: views from above the glass ceiling, International Journal of Contemporary Hotel Management, vol. 9/5/6/, pp. 230-235, 1997.

[38] Rocio, M. Gender and economic performance: Evidence from the Spanish hotel industry, International Journal of Hospitality Management, vol. 31/3, pp. 981-989, 2012.

[39] Booth, C., Bennet, C. Towards a new conception and practice if equal opportunities? European Journal of Women's Studies, vol. 9 (4), pp. 430-446, 2002.

[40] Davidson, M.J., Burke, R.J. Women in management worldwide, Facts, Figures and Analysis, Ashgate Publisher, England, 2004.

[41] Brownell, J., Walsh, K. Women in hospitality, The Sage Handbook of Hospitality Management, Sage Publications, California, 2008.

[42] Feifan, Xie, P. Developing industrial heritage tourism: A case study of the proposed jeep museum in Toledo, Ohio, Tourism Management vol. 27, pp. 1321-1330, 2006.

[43] Stojkovic, M. Statistical methods in tourism, Faculty of Science, Department of Geography, Tourism and Hotel Management, Novi Sad, 2008. 